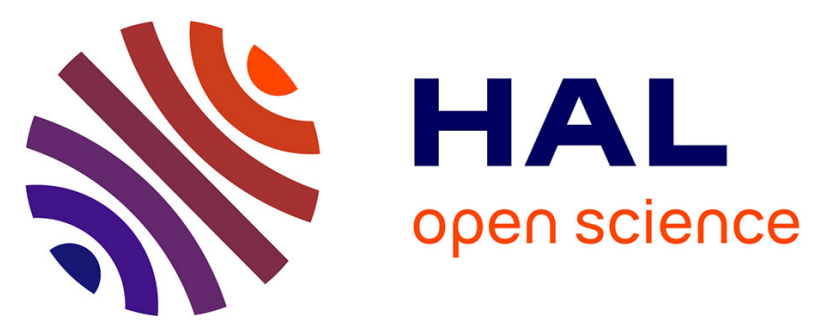

\title{
Simulating soil organic carbon in yedoma deposits during the Last Glacial Maximum in a land surface
}

D. Zhu, S. Peng, Philippe Ciais, R. Zech, Gerhard Krinner, S. Zimov, G. Grosse

\section{- To cite this version:}

D. Zhu, S. Peng, Philippe Ciais, R. Zech, Gerhard Krinner, et al.. Simulating soil organic carbon in yedoma deposits during the Last Glacial Maximum in a land surface. Geophysical Research Letters, 2016, 43 (10), pp.5133-5142. 10.1002/2016GL068874 . insu-01387799

HAL Id: insu-01387799

https://hal-insu.archives-ouvertes.fr/insu-01387799

Submitted on 17 Sep 2020

HAL is a multi-disciplinary open access archive for the deposit and dissemination of scientific research documents, whether they are published or not. The documents may come from teaching and research institutions in France or abroad, or from public or private research centers.
L'archive ouverte pluridisciplinaire HAL, est destinée au dépôt et à la diffusion de documents scientifiques de niveau recherche, publiés ou non, émanant des établissements d'enseignement et de recherche français ou étrangers, des laboratoires publics ou privés. 


\section{Geophysical Research Letters}

\section{RESEARCH LETTER}

10.1002/2016GL068874

Key Points:

- A sedimentation parameterization in a large-scale land surface model can simulate the buildup of deep carbon in yedoma

- Model results are evaluated against site measurements and regional inventories

- Simulated total soil organic carbon at the LGM is $390-446 \mathrm{Pg} \mathrm{C}$ within today's yedoma region

Supporting Information:

- Supporting Information S1

Correspondence to:

D. Zhu,

dan.zhu@lsce.ipsl.fr

\section{Citation:}

Zhu, D., S. Peng, P. Ciais, R. Zech, G. Krinner, S. Zimov, and G. Grosse (2016), Simulating soil organic carbon in yedoma deposits during the Last Glacial Maximum in a land surface model, Geophys. Res. Lett., 43, 5133-5142, doi:10.1002/2016GL068874.

Received 18 NOV 2015 Accepted 9 MAY 2016 Accepted article online 11 MAY 2016 Published online 21 MAY 2016

\section{Simulating soil organic carbon in yedoma deposits during the Last Glacial Maximum in a land surface model}

\author{
D. Zhu ${ }^{1}$, S. Peng ${ }^{1,2}$, P. Ciais ${ }^{1}$, R. Zech ${ }^{3}$, G. Krinner ${ }^{4}$, S. Zimov ${ }^{5}$, and G. Grosse ${ }^{6}$ \\ ${ }^{1}$ Laboratoire des Sciences du Climat et de l'Environnement, LSCE CEA CNRS UVSQ, Gif Sur Yvette, France, ${ }^{2}$ Sino-French \\ Institute for Earth System Science, College of Urban and Environmental Sciences, Peking University, Beijing, China, \\ ${ }^{3}$ Geographical Institute and Oeschger Centre for Climate Change Research, University of Bern, Bern, Switzerland, \\ ${ }^{4}$ Laboratoire de Glaciologie et Géophysique de l'Environnement (LGGE), CNRS, Grenoble, France, ${ }^{5}$ Northeast Science \\ Station, Pacific Institute for Geography, Russian Academy of Sciences, Cherskii, Russia, ${ }^{6}$ Alfred Wegener Institute, Helmholtz \\ Centre for Polar and Marine Research, Periglacial Research Unit, Potsdam, Germany
}

Abstract Substantial quantities of organic carbon $(O C)$ are stored in the thick, ice-rich, and organic-rich sediments called yedoma deposits, distributed in eastern Siberia and Alaska today. Quantifying yedoma carbon stocks during the glacial period is important for understanding how much carbon could have been decomposed during the last deglaciation. Yet processes that yield the formation of thick frozen OC in yedoma deposits are missing in global carbon cycle models. Here we incorporate sedimentation parameterizations into the Organizing Carbon and Hydrology In Dynamic Ecosystems (ORCHIDEE-MICT) land surface model, which leads to reasonable results in OC vertical distribution and regional budgets, compared with site-specific observations and inventories for today's nondegraded yedoma region. Simulated total soil OC stock for the northern permafrost region during the Last Glacial Maximum (LGM) is 1536-1592 Pg C, of which 390-446 Pg C is within today's yedoma region. This result is an underestimation since we did not account for the potentially much larger yedoma area during the LGM than the present day.

\section{Introduction}

Soils in the northern high-latitude permafrost regions contain large quantities of organic carbon [Zimov et al., 2006; Schuur et al., 2015]. Recent inventories suggest a total OC stock of 1300-1600 Pg C in circumpolar permafrost soils [Tarnocai et al., 2009; Hugelius et al., 2014], of which 210-460 Pg C is stored in the thick, frozen sediments in the yedoma region [Strauss et al., 2013; Walter Anthony et al., 2014]. Yedoma deposits were accumulated during tens of thousands of years during the late Pleistocene from various sediment sources and transport types (e.g., slope wash, alluvial runoff, and eolian transport). These soils are characterized by high ice content $(50-80 \%$ of the ground volume, including segregated ice in soil pores and surrounding large syngenetic ice wedges), relatively high OC content compared to nonpermafrost mineral soils ( $2-5 \%$, comprising substantial quantities of ancient plant detritus and animal remains), and a thickness ranging from $5 \mathrm{~m}$ to $50 \mathrm{~m}$ [Schirrmeister et al., 2013; Strauss et al., 2013; Walter Anthony et al., 2014; Schuur et al., 2015].

The deep soil organic matter in yedoma deposits is vulnerable to decomposition [Dutta et al., 2006; Schädel et al., 2014], since yedoma contains labile organic matter that was buried and frozen into permafrost during its slow formation. About $70 \%$ of the area presumably covered by yedoma deposits during the Last Glacial Maximum (LGM) has undergone thermokarst degradation or fluvial erosion during the Holocene, transforming the late Pleistocene accumulation plain into today's landscape of highly discontinuous yedoma deposits [Grosse et al., 2013; Strauss et al., 2013].

Quantifying permafrost carbon stocks during glacial periods is crucial for understanding the potential contribution of the land carbon reservoir to the $\sim 80 \mathrm{ppm}$ atmospheric $\mathrm{CO}_{2}$ rise during deglaciations, an issue that remains unresolved and in wide controversy [Sigman et al., 2010; Ciais et al., 2012; Zech, 2012; Köhler et al., 2014]. Considering the limitation of field studies due to potential disappearance of pedological evidence for glacial-period soil carbon storage, modeling may be essential to estimate permafrost carbon stocks during glacial periods [Zech et al., 2011]. However, the processes that result in the accumulation of thick OC deposits in yedoma-like permafrost soils and rapid release of carbon due to abrupt thaw are still absent from current large-scale models [Schuur et al., 2015]. 
In this study, we have added sedimentation parameterizations into the permafrost carbon module of ORCHIDEE-MICT global land surface model [Koven et al., 2009, 2011; Peng et al., 2015]. An advection equation proposed by Zimov et al. [2009] is implemented in ORCHIDEE-MICT to simulate vertical carbon distribution under sedimentation conditions. A similar advection term was included in the soil model of CLM4 (Community Land Model) [Koven et al., 2013a] but was used to represent soil OC movement through dissolved transport and was deactivated in their baseline runs. This sedimentation process in ORCHIDEE-MICT is therefore, to our knowledge, the first time that such a process has been included in a large-scale land surface model to simulate organic carbon buildup in yedoma deposits.

\section{Methods}

\subsection{Litter and Soil Carbon Dynamics in ORCHIDEE-MICT}

The schematic of ORCHIDEE-MICT litter and soil carbon dynamics is shown in supporting information Figure S1. The two litter carbon pools (metabolic and structural) and three soil pools (active, slow, and passive) are vertically discretized into 32 layers, with a total depth of $47.5 \mathrm{~m}$. Decomposition processes of the carbon pools and the resulting carbon flows between the pools are calculated at each layer, controlled by their residence times, soil temperature, moisture, and texture (see supporting information Text S1 and Figure S1).

Cryoturbation (mixing of soil layers driven by repeated freeze-thaw processes) is a major soil-forming process in arctic regions, redistributing organic matter from topsoil horizons into deeper soil layers [Kaiser et al., 2007]. Instead of explicitly modeling cryoturbation, a diffusion equation was implemented by Koven et al. [2009] to capture the effect of vertical mixing due to cryoturbation on soil carbon profiles. The diffusion rate is set constant through the active layer $\left(10^{-3} \mathrm{~m}^{2} \mathrm{yr}^{-1}\right.$ as in Koven et al. [2009]) and decreases linearly to 0 at the depth of 3 times the local active layer thickness (ALT), while ALT is simulated by the multilayer soil physical module in ORCHIDEE-MICT [Gouttevin et al., 2012]. It is worth noting that the glacial-period mammoth-steppe ecosystem may have been very different from today's tundra, characterized by intense aridity, deeper annual thaw, and deeper penetration of roots than in today's wet tundra [Guthrie, 2001; Zimov et al., 1995]. Cryoturbation during glacial periods may not have been as common as in modern arctic soils, due to reinforcement by roots and low soil moisture; instead, the role of zoogenic vertical mixing (by worms, beetles, etc.) may be significant, considering the high worm density (up to $100 \mathrm{~g} \mathrm{~m}^{-2}$ ) in today's analogous meadow in north Siberia (S. Zimov, unpublished data, 2015). Thus, we keep the original diffusion equations in the model for the LGM simulations in this study but leave room for future calibration of the diffusion-related parameters.

Yedoma deposits are on average $20 \mathrm{~m}$ thick with high spatial heterogeneity [Strauss et al., 2013], accumulated through various sediment formation processes under extreme cold climate in late Pleistocene [Schirrmeister et al., 2013]. When sediments are deposited on the soil surface, each soil layer sinks downward relative to the surface at a rate equal to the sedimentation rate, assuming that soil compression with depth is not significant [Zimov et al., 2009]. Thus, instead of modeling the upward accumulation of soil, we implemented a vertical advection equation in ORCHIDEE-MICT to simulate the equivalent downward transport of OC due to sediments aggrading on ground surface:

$$
\frac{\partial C_{i}(z, t)}{\partial t}+u(t) \frac{\partial C_{i}(z, t)}{\partial z}=f_{i}(z, t)-g_{i}(z, t) \times C_{i}(z, t)
$$

where $C_{i}(z, t)\left(\mathrm{g} \mathrm{m}^{-3}\right)$ is OC concentration of litter or soil carbon pool $i$ at depth $z$ and time $t ; u(t)\left(\mathrm{m} \mathrm{d}^{-1}\right)$ the sedimentation rate; $f_{i}(z, t)\left(\mathrm{g} \mathrm{m}^{-3} \mathrm{~d}^{-1}\right)$ the OC input to pool $i$; and $g_{i}(z, t)\left(\mathrm{d}^{-1}\right)$ the decomposition rate of pool $i$, using the frozen respiration function by Koven et al. [2011].

This equation is implemented numerically using a second-order finite difference scheme, the Van Leer scheme [Van Leer, 1977]. Since $\partial z$ in ORCHIDEE-MICT is very large for the lower layers (maximum of $7.3 \mathrm{~m}$ for the bottom layer), the vertical distribution of $O C$ shows large dissipation using finite difference schemes, i.e., a considerable amount of OC can be numerically transported to lower layers even though soil accumulation does not reach the corresponding depths of those layers. In order to limit numerical dissipation, we added a boundary for the transport of OC, i.e., only when the cumulative depth of sedimentation is deeper than the bottom of a layer can OC of this layer be transported to the next (lower) layer:

$$
u^{\prime}(z, t)= \begin{cases}u(t) & \text { if } z<=\int_{0}^{t} u(t) \mathrm{d} t+z_{0} \\ 0 & \text { if } z>\int_{0}^{t} u(t) \mathrm{d} t+z_{0}\end{cases}
$$


where $u^{\prime}(z, t)\left(\mathrm{m} \mathrm{d}^{-1}\right)$ is the sedimentation rate used in each soil layer; and $z_{0}(\mathrm{~m})$ the maximum depth of initial litter and soil OC distribution at $t=0\left(z_{0}=0\right.$ in this study).

\subsection{Model Setup and Evaluation}

Site level and regional level simulations were conducted with ORCHIDEE-MICT, starting from bare ground (i.e., fractional coverage of all plant function types, and biomass, litter, and soil organic carbon pools, start from zero), forced by LGM climate due to the lack of full time series of climate data during the last glacial period. The dynamic vegetation module in ORCHIDEE-MICT [Zhu et al., 2015] was activated to simulate vegetation fractions in equilibrium with LGM climate. Atmospheric $\mathrm{CO}_{2}$ concentration was fixed as $185 \mathrm{ppm}$. The climate forcing files were derived from the anomalies of LGM climate experiment outputs by the Institut Pierre Simon Laplace (IPSL) earth system model IPSL-CM5A-LR, with a 6-hourly time step and a spatial resolution of $1.875^{\circ} \times 3.75^{\circ}$ [Kageyama et al., 2013] (see supporting information Text S2).

\subsubsection{Site Simulation}

Schirrmeister et al. [2011a] compiled data from 14 sites of yedoma deposits in northern east Siberia with detailed sedimentological and geochronological information. The height-age slope of each section can provide the mean value of sedimentation rates for the corresponding period. Among the 14 sites, only five sites have an age range covering LGM (22-18 ky B.P.). We further excluded the sections with too few layers (less than three) to infer the sedimentation rate during LGM, leaving three sites (four sections) for evaluation (Table 1).

In order to compare OC concentration results from ORCHIDEE-MICT with site measurements of TOC (total organic carbon, defined as the weight ratio of organic carbon to soil dry mass, unit: wt \%), we converted TOC into OC using the following equations, assuming that the pore volume in yedoma deposits is ice saturated [Strauss et al., 2013; Schirrmeister et al., 2011b]:

$$
\begin{aligned}
& \mathrm{BD}\left(10^{3} \mathrm{~kg} \mathrm{~m}^{-3}\right)=\frac{1}{\frac{1}{\rho_{s}}+\left(\frac{\text { ice }(\mathrm{wt} \%) / 100}{\rho_{i}}\right)} \\
& \mathrm{OC}\left(\mathrm{kg} \mathrm{m}^{-3}\right)=\mathrm{BD}\left(\mathrm{kg} \mathrm{m}^{-3}\right) \times \frac{100-\mathrm{WIV}(\mathrm{vol} \%)}{100} \times \frac{\mathrm{TOC}(\mathrm{wt} \%)}{100}
\end{aligned}
$$

where $\mathrm{BD}$ is the bulk density of yedoma deposits; $\rho_{s}$ is assumed to be $2.65 \times 10^{3}\left(\mathrm{~kg} \mathrm{~m}^{-3}\right)$, representing density of the solid fraction after oven drying [Strauss et al., 2013]; $\rho_{i}=0.91 \times 10^{3}\left(\mathrm{~kg} \mathrm{~m}^{-3}\right)$, representing ice density; ice (wt \%) is the weight ratio of ice in a sample to the dry sample, measured at different depth in a section, representing segregated ice content in yedoma deposits; since ice contents were not measured for all samples, we linearly interpolate ice along the depth for the TOC values without corresponding ice; WIV (vol\%) is the volume percentage of wedge ice in yedoma deposits; here we use the mean value of 47.9 (vol \%) with the range 34.7-59.0 (vol \%), estimated by Strauss et al. [2013].

ORCHIDEE-MICT cannot explicitly simulate a composite soil made of sediments and surrounding ice wedges, as it only simulates carbon dynamics and not the changes in soil volume resulting from sedimentation and syngenetic growing of ice wedges [Schirrmeister et al., 2013]. The model result for litter and soil OC represents the average concentration of a grid cell, given the fact that ice wedges only exist below the active layer (unless erosion occurs), so that plants occupy the full surface area of a grid cell if climate permits. Therefore, ice wedge volume is subtracted from the measured OC concentrations as in equation (3) to derive a landscape-scale mean OC concentration that is comparable to model results. Note that the sedimentation rate is diagnosed from the measured depth-age relationship in yedoma deposits, which results from both deposition and growth of ice wedges and segregated ice that takes space; the effect of ice formation is thus implicitly included in the sedimentation rate used in equation (1) to advect OC downwards.

2.2.2. Regional Simulation

ORCHIDEE-MICT was run for the Northern Hemisphere $\left(>20^{\circ} \mathrm{N}\right)$, without (hereafter "CTRL") and with (hereafter "SEDI") sedimentation parameterizations. In SEDI, sedimentation processes were activated only over present-day yedoma regions, including an area of 1.14 million $\mathrm{km}^{2}$ in north and east Siberia [Romanovskii, 1993] and an area of 0.18 million $\mathrm{km}^{2}$ in Alaska [Jorgenson et al., 2008]. During the LGM, the area where sedimentation occurred could have been much larger than today's yedoma area. But the goal of this study is to evaluate modeled and observed $\mathrm{OC}$ at sites and regions where yedoma has survived the Holocene warmer period, not to 


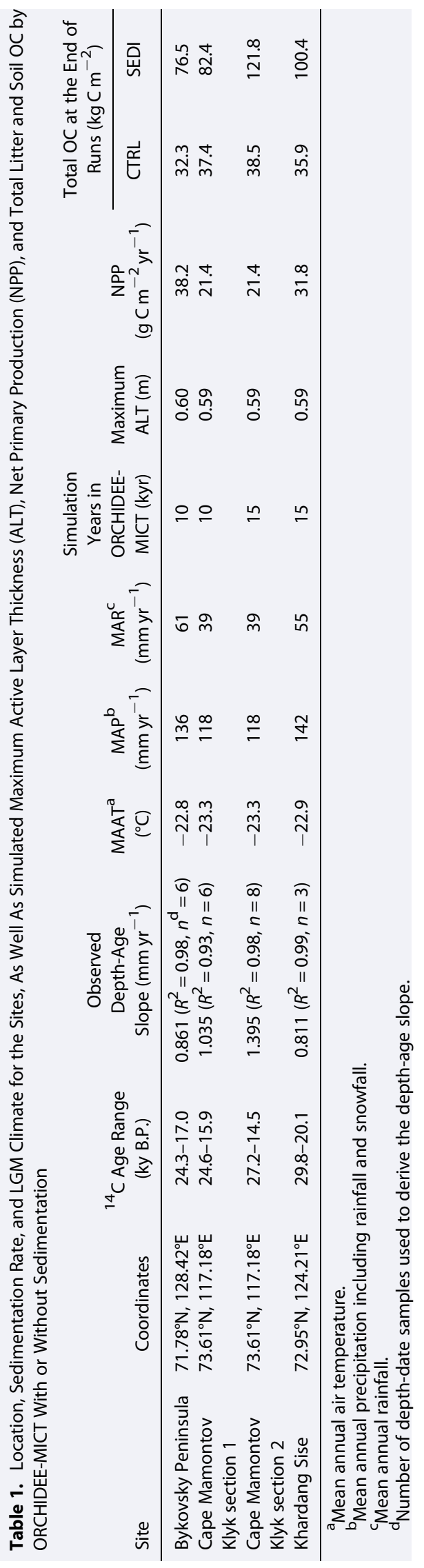

calculate the full amount of OC in yedoma during the LGM; so LGM yedoma areas that disappeared during the deglaciation are not covered in this study.

We tested different values for sedimentation rates, 0.6, 0.8, 1.0 , and $1.2 \mathrm{~mm} \mathrm{yr}^{-1}$, which are typical rates during the LGM observed in yedoma sites [Schirrmeister et al., 2011a]; correspondingly, ORCHIDEE-MICT was run for different time periods $(32,24,19$, and $16 \mathrm{kyr})$ of the late Pleistocene assuming that climate remained the one of LGM, in order to reach a thickness of $19.4 \mathrm{~m}$, which is the mean yedoma deposit thickness suggested by Strauss et al. [2013]. The OC of each litter and soil layer and each grid cell within the yedoma region were summed up to derive their total carbon at the LGM.

\section{Results}

\subsection{Site Simulation}

As listed in Table 1, mean annual air temperature and precipitation at the three sites during the LGM was about $-23^{\circ} \mathrm{C}$ and $118-140 \mathrm{~mm} \mathrm{yr}^{-1}$ (versus $-15^{\circ} \mathrm{C}$ and $196-259 \mathrm{~mm} \mathrm{yr}^{-1}$ for 1951-2000 mean from CRU-NCEP data set (available online: http://dods.extra.cea.fr/data/p529viov/cruncep/)), according to the results of IPSL-CM5A-LR (after bias correction mentioned in Text S2). Site-observed sedimentation rates are relatively constant from 30 ky B.P. to 15 ky B.P. ( $R^{2}$ for depth-age regression higher than 0.9 ), ranging from 0.8 to $1.4 \mathrm{~mm} \mathrm{yr}^{-1}$ among the four sections. Simulated dominant vegetation is C3 grass for all sites, with areal coverage above 95\%. Net primary productivity (NPP) in equilibrium with LGM climate ranges from 21 to $38 \mathrm{~g} \mathrm{C} \mathrm{m}^{-2} \mathrm{yr}^{-1}$, which is lower than the productivity of modern steppe meadows in Siberia that are close analogues of periglacial communities (36-76 $\mathrm{g} \mathrm{C} \mathrm{m}^{-2} \mathrm{yr}^{-1}$ [Velichko and Zelikson, 2005]), partly due to lower $\mathrm{CO}_{2}$ levels and the very severe climate at the three sites compared to the average climate of east Siberia.

The vertical profiles of litter and soil OC simulated by CTRL and SEDI for the four yedoma sections are shown in Figure 1a. For CTRL, OC can accumulate only in the upper $\sim 2 \mathrm{~m}$, limited by the maximum mixing (cryoturbation) depth dependent on local ALT. When sedimentation is considered, however, the slow buildup of yedoma sequences is reproduced after 10 or $15 \mathrm{kyr}$ of simulation. Despite lower OC concentrations in the top $2 \mathrm{~m}$, the total column OC for the four sections in SEDI $\left(76-122 \mathrm{~kg} \mathrm{Cm}^{-2}\right)$ is much higher than those in CTRL (32-39 $\mathrm{kg} \mathrm{C} \mathrm{m}^{-2}$ ), due to deeper carbon distributions. The total column OC in SEDI is lower than, but not directly comparable to, the measured OC content at five sites by Schirrmeister et al. [2011b] $\left(180-910 \mathrm{~kg} \mathrm{C} \mathrm{m}^{-2}\right)$, because (1) the column OC in Schirrmeister et al. [2011b] corresponded to the deposits without accounting for ice wedge volume, while the model results represent landscape-scale average including ice wedge volume; (2) the column OC in Schirrmeister et al. [2011b] considered full depth of the 
(a)

O Observation (Schirrmeister et al., 2011a)

-0 ORCHIDEE-CTRL

-O-ORCHIDEE-SEDI

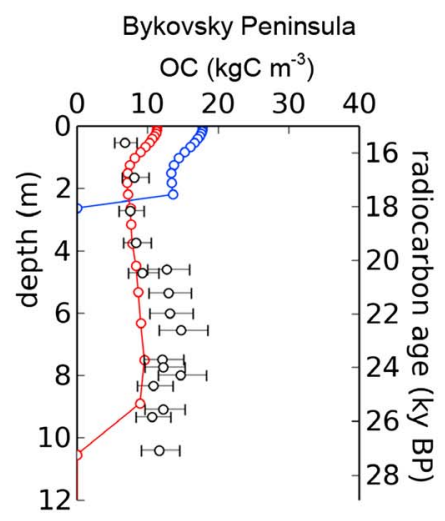

\section{Cape Mamontov Klyk section 1} $\mathrm{OC}\left(\mathrm{kgC} \mathrm{m}^{-3}\right)$

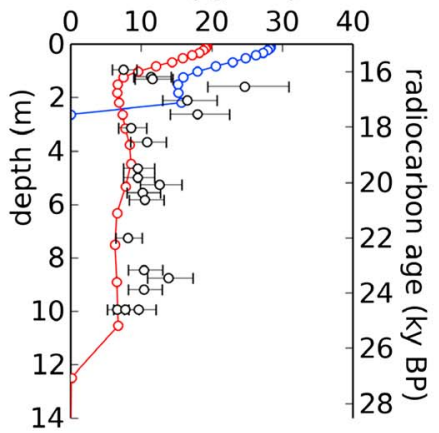

Cape Mamontov Klyk section 2 $\mathrm{OC}\left(\mathrm{kgC} \mathrm{m}^{-3}\right)$

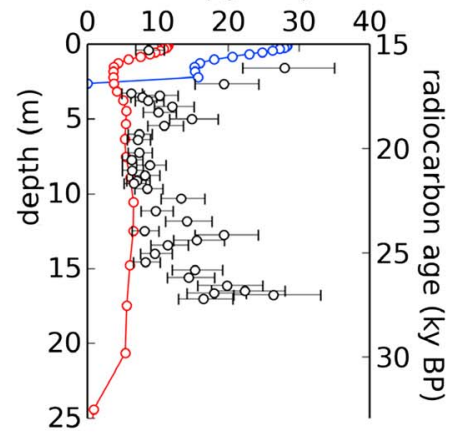

Khardang Sise $\mathrm{OC}\left(\mathrm{kgC} \mathrm{m}^{-3}\right)$

(b)
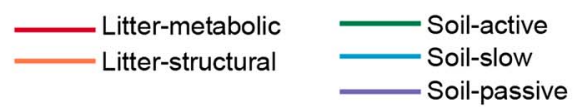

--- Simulated rate of $\mathrm{CO}_{2}$ release if incubated at $5^{\circ} \mathrm{C}$

Fraction of litter and soil carbon pools (100\%)
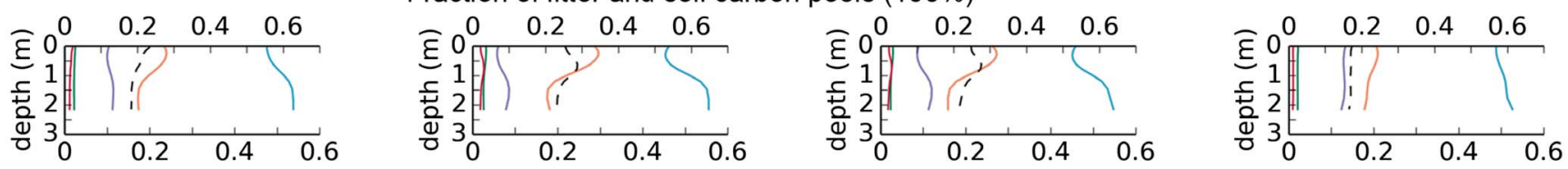

Simulated rate of $\mathrm{CO}_{2}$ release if incubated at $5^{\circ} \mathrm{C}\left(\mathrm{mgC} \mathrm{g}^{-1} \mathrm{C}{ }^{-1}\right)$

(c)

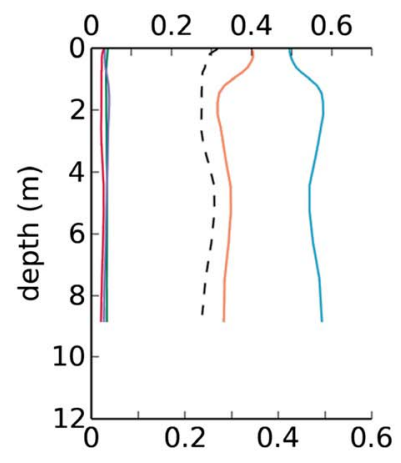

Fraction of litter and soil carbon pools (100\%)
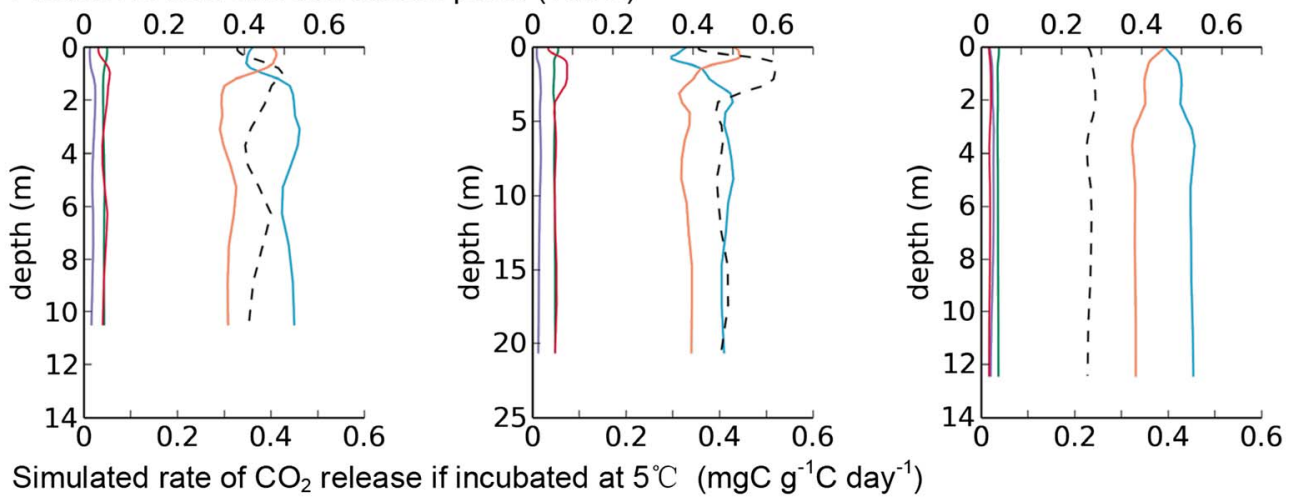

Figure 1. (a) Vertical profiles of litter and soil OC simulated by ORCHIDEE-MICT without (blue) and with (red) sedimentation parameterization, with circles symbolizing the depth of each soil layer in the model. The black circles indicate measurements corresponding to different ages (the right $y$ axis) from Schirrmeister et al. [2011a]. The depths and ages are linearly correlated through the constant sedimentation rates (Table 1), with the surface corresponding to the age 15 ky B.P. Simulated decomposability of litter and soil OC (b) without and (c) with sedimentation. The upper $x$ axis and colored lines indicate the fractions of each carbon pool, and the lower $x$ axis and dashed lines indicate simulated initial $\mathrm{CO}_{2}$ production rates using the structure and parameters of the soil module in ORCHIDEE-MICT, assuming constant temperature of $5^{\circ} \mathrm{C}$ and optimal moisture condition.

deposits, while the site simulations were only run for the period of relatively constant sedimentation rates, with a final OC depth of 9-21 m.

Simulated OC concentrations by SEDI are generally within the range of field measurements in the two sites in Bykovsky Peninsula and Khardang Sise but are underestimated in the two sections in Mamontovy Klyk (Figure 1a). This underestimation can be partly explained by the permanent severe LGM climate that is used as model input, in contrast to the reality that warmer and wetter periods existed during the 10 or $15 \mathrm{kyr}$ time scale considered in the site simulations [Wetterich et al., 2008]. Besides, the coarse resolution of climate 
forcing produced by IPSL-CM5A-LR may not capture the local-scale climate features at the sites considered. In order to illustrate the response of the modeled litter and soil OC under warmer/wetter climates, idealized sensitivity tests were conducted with temperature increased by 1 or $2^{\circ} \mathrm{C}$ and rainfall increased by $50 \%$ or $100 \%$ (Figure S2). At the sites, NPP barely changed in the model under higher temperatures alone but greatly increased under higher rainfalls. Litter and soil OC were slightly lower under higher temperatures alone due to enhanced decomposition, while under higher rainfalls alone or combined warmer and wetter conditions, litter and soil OC increased proportionately to the increase of NPP and better matched the measurements at the Mamontovy Klyk sections (Figure S2). These results illustrate the uncertainties of modeled $\mathrm{OC}$ induced by the uncertain climate forcing and by the permanent harsh LGM climate conditions assumed throughout the time frame considered.

For the decomposability of litter and soil OC, the simulated fractions of the relatively labile pools (litter and active soil) are higher in SEDI (Figure 1c) than in CTRL (Figure 1b), since more labile OC is buried and preserved in frozen layers in SEDI before decomposition. Initial $\mathrm{CO}_{2}$ production rates were calculated by simulating incubation experiments (Figures $1 \mathrm{~b}$ and $1 \mathrm{c}$ ). This is done using the structure and parameters of the ORCHIDEE-MICT soil module (Figure $\mathrm{S} 1$ ) and simulating $\mathrm{CO}_{2}$ respired in each soil layer when it is exposed to a constant incubation temperature of $5^{\circ} \mathrm{C}$ and optimal moisture condition. The initial $\mathrm{CO}_{2}$ release rates averaged over the depth below the active layer are $0.23-0.41 \mathrm{mg} \mathrm{Cg}^{-1} \mathrm{C}_{\text {day }}{ }^{-1}$ in SEDI, 56-110\% higher than that in CTRL $\left(0.14-0.21 \mathrm{mg} \mathrm{Cg}^{-1} \mathrm{C}_{\text {day }}{ }^{-1}\right)$, with larger increases in the case of larger sedimentation rates (e.g., the relative increase in Mamontovy Klyk section 2 is larger than section 1, 110\% versus 79\%). To compare the modeled lability in SEDI with the laboratory incubation results for deep yedoma soil samples by Dutta et al. [2006], Lee et al. [2012], and Knoblauch et al. [2013], we calculated $\mathrm{CO}_{2}$ release rates under different conditions corresponding to the three studies (under 5,15 , and $4^{\circ} \mathrm{C}$, respectively, averaged over 30,500, and 30 days, respectively). The lability in SEDI is comparable to the results in Dutta et al. [2006] (0.2-0.3 versus modeled $\left.0.22-0.39 \mathrm{mg} \mathrm{C} \mathrm{g}^{-1} \mathrm{C} \mathrm{day}^{-1}\right)$ and in Lee et al. [2012] (0.22-0.29 versus modeled $0.23-0.31 \mathrm{mg} \mathrm{Cg}^{-1} \mathrm{C}$ day $\left.^{-1}\right)$, yet higher than that in Knoblauch et al. [2013] (0.04-0.16 versus modeled $0.21-0.37 \mathrm{mg} \mathrm{C} \mathrm{g}^{-1}\left(\right.$ day $\left.^{-1}\right)$.

\subsection{Regional Simulation}

Total litter and soil carbon in the Northern Hemisphere $\left(>20^{\circ} \mathrm{N}\right.$, a total land area of 67.4 million $\left.\mathrm{km}^{2}\right)$ is $1418 \mathrm{PgC}$ simulated by CTRL (Figure 2a). High carbon density is obtained for grid cells where cryoturbation occurs in the model (Figures $2 \mathrm{a}$ and $2 \mathrm{~b}$ ), set as pixels with maximum ALT less than $1 \mathrm{~m}$ [Koven et al., 2009]. Simulated LGM permafrost extent is 36.6 million $\mathrm{km}^{2}$ (defined as grid cells with maximum ALT less than $3 \mathrm{~m}$, according to Koven et al. [2013b]; Figure 2b), close to the reconstruction of Lindgren et al. [2015] based on field evidence ( 34.5 million $\mathrm{km}^{2}$ ). Total litter and soil carbon stock in simulated LGM permafrost region is $1220 \mathrm{Pg} C$ in CTRL without deep carbon in the yedoma region and 1536-1592 Pg C in SEDI with deep carbon in the present-day yedoma region.

The spatial distributions of litter and soil carbon simulated by SEDI in regions covered by present-day yedoma are shown in Figure 2c. The tests with different sedimentation rates show similar patterns. In SEDI, litter and soil carbon stock in today's yedoma region (total area of 1.32 million $\mathrm{km}^{2}$ ) is $390-446 \mathrm{Pg} \mathrm{C}$, depending on the sedimentation rate and simulation years in the model, much higher than that in CTRL (74 PgC). The SEDI result is very close to the estimation by Walter Anthony et al. [2014] (429 $\pm 101 \mathrm{Pg} \mathrm{C)}$ for the LGM carbon pool in the same yedoma territory, based on extrapolated current observations. If we apply the mask of today's undisturbed, fragmented yedoma deposits (total area of 0.42 million $\mathrm{km}^{2}$ [Grosse et al., 2013]) on the simulated OC distribution, a total value of $125-145 \mathrm{PgC}$ is derived for today's yedoma deposits, which is within the upper part of the range estimated by Strauss et al. [2013] $(83+61 /-57 \mathrm{Pg} \mathrm{C})$. Note that the model was forced by stable (but interannual variable) LGM climate and constant sedimentation rate in each simulation. A more realistic simulation of yedoma carbon stock would need to consider transient climate forcing during the late Pleistocene and sedimentation rate variations in time and space.

\section{Discussion}

The inclusion of sedimentation parameterizations in ORCHIDEE-MICT allows the model to reproduce the accumulation of deep organic carbon below $3 \mathrm{~m}$ in yedoma regions, leading to a several-fold increase in total carbon after tens of thousand years of simulation, in better agreement with observations at both site and 


\section{(a) Total litter and soil OC ORCHIDEE-CTRL}

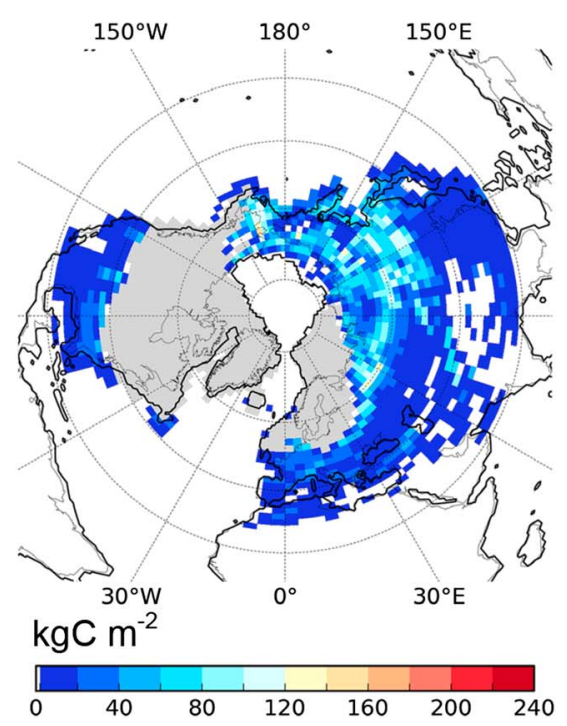

(b) Present-day Yedoma distribution (c) Total litter and soil OC ORCHIDEE-SEDI

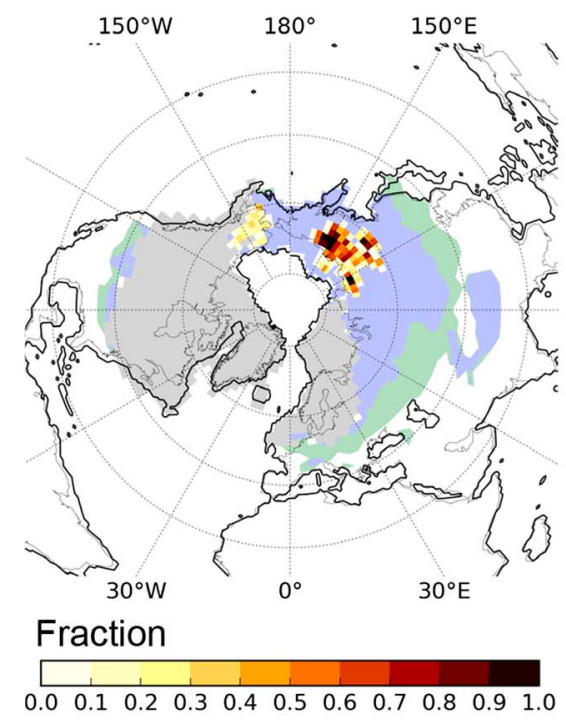

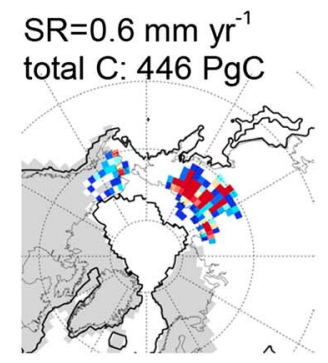

$\mathrm{SR}=1.0 \mathrm{~mm} \mathrm{yr}^{-1}$ total C: $413 \mathrm{PgC}$

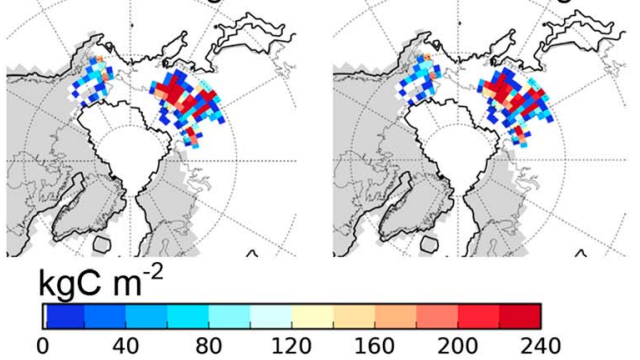

Figure 2. (a) ORCHIDEE-MICT litter and soil carbon density at LGM, without sedimentation parameterizations. (b) Fractions of present-day yedoma in each grid, aggregated to the model resolution from the original maps for Siberia [Romanovskii, 1993] and Alaska [Jorgenson et al., 2008]. Blue: the region where cryoturbation occurs in the model, set as grid cells with maximum ALT less than $1 \mathrm{~m}$ [Koven et al., 2009]. Green: simulated LGM permafrost region, defined as grid cells with maximum ALT less than $3 \mathrm{~m}$, according to Koven et al. [2013b]. (c) ORCHIDEE-MICT litter and soil carbon in yedoma region, with different sedimentation rates (SR); the total litter and soil carbon stocks for yedoma region are labeled in each subplot.

regional levels. Uncertainties of model results partly come from uncertainties in LGM climate, which in this study are obtained from the bias-corrected output of IPSL-CM5A-LR for Paleoclimate Modelling Intercomparison Project phase 3/Coupled Model Intercomparison Project phase 5 (PMIP3/CMIP5) experiments. Evaluations against palaeoclimate reconstructions show that the current generation of climate models used for CMIP5 have limited capabilities in capturing subcontinental patterns of temperature and precipitation for LGM [Harrison et al., 2015]. Using the ensemble of PMIP3 models may provide a climate forcing-induced uncertainty range for the simulated yedoma carbon stock, but the result should not change significantly since the LGM anomalies of temperature and precipitation simulated by IPSL-CM5A-LR are very close to the ensemble average of all available PMIP3/CMIP5 models [Harrison et al., 2015].

Soil OC quality (decomposability) is an important factor in determining the release rate and amount of permafrost carbon that can be transferred to the atmospheric reservoir in the case of soil warming. The OC quality is affected by the mechanisms through which OC was incorporated into permafrost [Schuur et al., 2008]. The deep yedoma soils have been shown to have distinct characteristics from other mineral soils near the surface, with high OC labilities comparable to that of surface organic soils, despite their lower bulk OC contents [Lee et al., 2012; Schädel et al., 2014]. The model results in this study demonstrate the substantial effect of sedimentation processes on the simulated decomposability of soil OC, highlighting the importance of those processes in land surface models applied to simulate the potential permafrost carbon release both during the last deglaciation and subject to future climate change.

Litter and soil carbon content is closely related to vegetation productivity. The average gross primary production per unit area and total area for grassland in the Northern Hemisphere $\left(>20^{\circ} \mathrm{N}\right)$ simulated in this study are $213 \mathrm{~g} \mathrm{C} \mathrm{m}^{-2} \mathrm{yr}^{-1}$ and 35 million $\mathrm{km}^{2}$, smaller than the estimation by Ciais et al. [2012] using a Bayesian inversion model constrained by the global mass balance of ${ }^{13} \mathrm{C}$ in different carbon reservoirs $\left(244 \mathrm{~g} \mathrm{C} \mathrm{m}^{-2} \mathrm{yr}^{-1}\right.$ and 45 million $\left.\mathrm{km}^{2}\right)$. The underestimation of grassland distribution and productivity may be partly explained by the lack of herbivore-vegetation interactions in ORCHIDEE-MICT. Large herbivores inhibit the growth and expansion of moss, shrub, and tree by trampling; fertilize the soil by accelerating the nutrient turnover; and indirectly affect soil properties by changing vegetation structure 
and trampling snow in winter [Zimov et al., 1995; Olofsson et al., 2009; Gill, 2014]. Reconstructions of ice age megafaunal population based on bone collections showed a biomass density of about $10 \mathrm{t} \mathrm{km}^{-2}$ in both Siberia [Zimov et al., 2012] and Arctic Alaska [Mann et al., 2013], comparable to that in today's African savannah [Hatton et al., 2015]. Considering the productivity needed to sustain such large densities of mammals and their feedbacks on vegetation [Yurtsev, 2001], a more realistic simulation of grassland distribution and productivity and subsequent litter and soil carbon stocks during last ice age calls for the integration of herbivore-vegetation interactions in models aiming to reproduce the LGM terrestrial carbon cycle.

The simulated total litter and soil carbon stock in the LGM permafrost region (1540-1590 Pg C) is higher than the LGM "conventional" land carbon stock (total terrestrial biomass and soil carbon excluding permafrost) estimated by Ciais et al. [2012] (1340 $\pm 500 \mathrm{Pg} \mathrm{C}$, indirectly using global isotopic measurements and fixed carbon content per unit area of each biome) and by Prentice et al. [2011] (1070 Pg C, simulated by Land Processes and eXchanges dynamic global vegetation model). The simulated yedoma carbon stock accounts for more than $25 \%$ of this LGM permafrost carbon pool, even though it covers a small percentage of the simulated permafrost area ( 4\%). In this study, we only simulated the deep carbon in today's yedoma region; yet about 3 million $\mathrm{km}^{2}$ of today's arctic shelves that were exposed as unglaciated land during the last ice age, and another about 5 million $\mathrm{km}^{2}$ of thick $(>5-10 \mathrm{~m}$ ) sediments in the northern permafrost zone outside yedoma regions [Schuur et al., 2015], is not regarded as yedoma in our simulations but could have partially accumulated thick carbon-rich sediments similar to yedoma deposits. Expanding the sedimentation processes to a more realistic spatial distribution of yedoma-like soils could substantially increase the estimation of the total LGM permafrost carbon pool. Next steps of model application in this direction should combine reconstructed Pleistocene loess distribution and accumulation rates and extrapolation based on similar conditions to the known yedoma region in terms of climate, topography, vegetation, and dust deposition.

The incorporation of sedimentation processes in permafrost environments leads to an ever-changing litter and soil carbon pool without an equilibrium, which has important implications for the role of high-latitude terrestrial ecosystems in the global carbon cycle. On the one hand, the gradual sequestration of $\mathrm{CO}_{2}$ in the thick sediments of the permafrost region during cold periods may provide an explanation for the long-term decrease of atmospheric $\mathrm{CO}_{2}$ during the late Pleistocene [Ahn and Brook, 2008]. On the other hand, setting a large "negative" sedimentation rate in equation (1) could mimic the upward movement of deep soil layers relative to the surface due to thermal erosion and associated ground subsidence (e.g., as observed in the real world following the collapse of ice wedges under warming), exposing previously frozen labile carbon to temperatures at which decomposition can occur. This could be a mechanism through which permafrost carbon losses are accelerated under warming conditions in a model, in contrast to the hypothesis of gradual active layer deepening that current models use for future projections [Koven et al., 2013b; Schaefer et al., 2014]. Processes of abrupt permafrost thaw and surface soil collapse are still missing in current global-scale models [Schuur et al., 2015]. To simulate abrupt thaw, Schneider von Deimling et al. [2015] calibrated the calculation of thaw rates in their simplified two-dimensional soil model, so that ALT could increase by more than $10 \mathrm{~m}$ at 2100 under RCP2.6 in the case of thermokarst formation; in the frame of our model, a negative sedimentation provides a possible method that works in another way to mobilize deep frozen carbon. Knowing that much work is still needed with regard to simulating hydrology and thermokarst dynamics related to permafrost thaw, the model described in this study takes a step forward and will help to simulate the potential significant contribution of permafrost to the atmospheric $\mathrm{CO}_{2}$ rise during glacial-interglacial transitions [Ciais et al., 2012; Zech, 2012], as well as future carbon emissions from permafrost.

Acknowledgments
We thank P. Peylin, P. Kuhry, and N. Viovy for helpful comments on the draft and M. Kageyama for providing the climate forcing data from IPSL-CM5A-LR experiments. D. Zhu received a $\mathrm{PhD}$ grant funded through the SwedishFrench "GAP" project; P. Ciais and S. Peng acknowledge support from the European Research Council through Synergy grant ERC-2013-SyG-610028 "IMBALANCE-P"; R. Zech is funded by the Swiss National Science Foundation (PP0OP2_150590); and G. Grosse is supported by ERC 338335 . The data used are listed in the references and tables. Any additional data and source code may be obtained from D.Z.

\section{References}

Ahn, J., and E. J. Brook (2008), Atmospheric $\mathrm{CO}_{2}$ and climate on millennial time scales during the last glacial period, Science, 322, 83-85, doi:10.1126/science.1160832.

Ciais, P., et al. (2012), Large inert carbon pool in the terrestrial biosphere during the Last Glacial Maximum, Nat. Geosci., 5(1), 74-79, doi:10.1038/ngeo1324. Dutta, K., E. A. Schuur, J. C. Neff, and S. A. Zimov (2006), Potential carbon release from permafrost soils of northeastern Siberia, Global Change Biol., 12(12), doi:10.1111/j.1365-2486.2006.01259.x.

Gill, J. L. (2014), Ecological impacts of the late Quaternary megaherbivore extinctions, New Phytol., 201(4), 1163-1169, doi:10.1111/nph.12576.

Gouttevin, I., G. Krinner, P. Ciais, J. Polcher, and C. Legout (2012), Multi-scale validation of a new soil freezing scheme for a land-surface model with physically-based hydrology, Cryosphere, 6(2), 407-430, doi:10.5194/tc-6-407-2012.

Grosse, G., J. E. Robinson, R. Bryant, M. D. Taylor, W. Harper, A. DeMasi, E. Kyker-Snowman, A. Veremeeva, L. Schirrmeister, and J. Harden (2013), Distribution of late Pleistocene ice-rich syngenetic permafrost of the Yedoma Suite in east and central Siberia, Russia, U.S. Geol. Surv. Open File Rep., 2013-1078, 37 p. 
Guthrie, R. D. (2001), Origin and causes of the mammoth steppe: A story of cloud cover, woolly mammal tooth pits, buckles, and inside-out Beringia, Quat. Sci. Rev., 20(1-3), 549-574, doi:10.1016/S0277-3791(00)00099-8.

Harrison, S. P., P. J. Bartlein, K. Izumi, G. Li, J. Annan, J. Hargreaves, P. Braconnot, and M. Kageyama (2015), Evaluation of CMIP5 palaeo-simulations to improve climate projections, Nat. Clim. Change, 5(8), 735-743.

Hatton, I. A., K. S. McCann, J. M. Fryxell, T. J. Davies, M. Smerlak, A. R. E. Sinclair, and M. Loreau (2015), The predator-prey power law: Biomass scaling across terrestrial and aquatic biomes, Science, 349(6252), doi:10.1126/science.aac6284.

Hugelius, G., et al. (2014), Estimated stocks of circumpolar permafrost carbon with quantified uncertainty ranges and identified data gaps, Biogeosciences, 11(23), 6573-6593, doi:10.5194/bg-11-6573-2014.

Jorgenson, M. T., K. Yoshikawa, M. Kanveskiy, Y. Shur, V. Romanovsky, S. Marchenko, G. Grosse, J. Brown, and B. Jones (2008), Permafrost characteristics of Alaska, Proc. Ninth Int. Conf. Permafr., 3, 121-122.

Kageyama, M., et al. (2013), Mid-Holocene and Last Glacial Maximum climate simulations with the IPSL model—Part I: Comparing IPSL CM5A to IPSL CM4, Clim. Dyn., 40(9-10), 2447-2468, doi:10.1007/s00382-012-1488-8.

Kaiser, C., H. Meyer, C. Biasi, O. Rusalimova, P. Barsukov, and A. Richter (2007), Conservation of soil organic matter through cryoturbation in arctic soils in Siberia, J. Geophys. Res., 112, G02017, doi:10.1029/2006JG000258.

Knoblauch, C., C. Beer, A. Sosnin, D. Wagner, and E.-M. Pfeiffer (2013), Predicting long-term carbon mineralization and trace gas production from thawing permafrost of northeast Siberia, Global Change Biol., 19(4), 1160-1172, doi:10.1111/gcb.12116.

Köhler, P., G. Knorr, and E. Bard (2014), Permafrost thawing as a possible source of abrupt carbon release at the onset of the Bølling/Allerød, Nat. Commun., 5, 5520, doi:10.1038/ncomms6520.

Koven, C. D., B. Ringeval, P. Friedlingstein, P. Ciais, P. Cadule, D. Khvorostyanov, G. Krinner, and C. Tarnocai (2011), Permafrost carbon-climate feedbacks accelerate global warming, Proc. Natl. Acad. Sci. U. S. A., 108(36), 14,769-14,774, doi:10.1073/pnas.1103910108.

Koven, C. D., W. J. Riley, Z. M. Subin, J. Y. Tang, M. S. Torn, W. D. Collins, G. B. Bonan, D. M. Lawrence, and S. C. Swenson (2013a), The effect of vertically resolved soil biogeochemistry and alternate soil C and N models on C dynamics of CLM4, Biogeosciences, 10(11), 7109-7131, doi:10.5194/bg-10-7109-2013.

Koven, C. D., W. J. Riley, and A. Stern (2013b), Analysis of permafrost thermal dynamics and response to climate change in the CMIP5 Earth System Models, J. Clim., 26(6), 1877-1900, doi:10.1175/JCLI-D-12-00228.1.

Koven, C., P. Friedlingstein, P. Ciais, D. Khvorostyanov, G. Krinner, and C. Tarnocai (2009), On the formation of high-latitude soil carbon stocks: Effects of cryoturbation and insulation by organic matter in a land surface model, Geophys. Res. Lett., 36, L21501, doi:10.1029/2009GL040150.

Lee, H., E. A. G. Schuur, K. S. Inglett, M. Lavoie, and J. P. Chanton (2012), The rate of permafrost carbon release under aerobic and anaerobic conditions and its potential effects on climate, Global Change Biol., 18(2), 515-527, doi:10.1111/j.1365-2486.2011.02519.x.

Lindgren, A., G. Hugelius, P. Kuhry, T. R. Christensen, and J. Vandenberghe (2015), GIS-based maps and area estimates of Northern Hemisphere permafrost extent during the Last Glacial Maximum, Permafr. Periglac. Process., doi:10.1002/ppp.1851.

Mann, D. H., P. Groves, M. L. Kunz, R. E. Reanier, and B. V. Gaglioti (2013), Ice-age megafauna in Arctic Alaska: Extinction, invasion, survival, Quat. Sci. Rev., 70, 91-108, doi:10.1016/j.quascirev.2013.03.015.

Olofsson, J., L. Oksanen, T. Callaghan, P. E. Hulme, T. Oksanen, and O. Suominen (2009), Herbivores inhibit climate-driven shrub expansion on the tundra, Global Change Biol., 15(11), 2681-2693, doi:10.1111/j.1365-2486.2009.01935.x.

Peng, S., et al. (2015), Simulated high-latitude soil thermal dynamics during the past four decades, Cryosphere Discuss., 9(2), 2301-2337, doi:10.5194/tcd-9-2301-2015.

Prentice, I. C., S. P. Harrison, and P. J. Bartlein (2011), Global vegetation and terrestrial carbon cycle changes after the last ice age, New Phytol., 189(4), 988-998, doi:10.1111/j.1469-8137.2010.03620.x.

Romanovskii, N. N. (1993), Fundamentals of Cryogenesis of Lithosphere, 336 pp., Moscow University Press, Moscow.

Schädel, C., E. A. G. Schuur, R. Bracho, B. Elberling, C. Knoblauch, H. Lee, Y. Luo, G. R. Shaver, and M. R. Turetsky (2014), Circumpolar assessment of permafrost $C$ quality and its vulnerability over time using long-term incubation data, Global Change Biol., 20(2), 641-652, doi:10.1111/gcb.12417.

Schaefer, K., H. Lantuit, V. E. Romanovsky, E. A. G. Schuur, and R. Witt (2014), The impact of the permafrost carbon feedback on global climate, Environ. Res. Lett., 9(8), 085003, doi:10.1088/1748-9326/9/8/085003.

Schirrmeister, L., V. Kunitsky, G. Grosse, S. Wetterich, H. Meyer, G. Schwamborn, O. Babiy, A. Derevyagin, and C. Siegert (2011a), Sedimentary characteristics and origin of the Late Pleistocene Ice Complex on north-east Siberian Arctic coastal lowlands and islands-A review, Quaternary Int., 241(1-2), 3-25, doi:10.1016/j.quaint.2010.04.004.

Schirrmeister, L., G. Grosse, S. Wetterich, P. P. Overduin, J. Strauss, E. A. G. Schuur, and H.-W. Hubberten (2011b), Fossil organic matter characteristics in permafrost deposits of the northeast Siberian Arctic, J. Geophys. Res., 116, G00M02, doi:10.1029/2011JG001647.

Schirrmeister, L., D. Froese, V. Tumskoy, G. Grosse, and S. Wetterich (2013), Yedoma: Late Pleistocene ice-rich syngenetic permafrost of Beringia, Encycl. Quaternary Sci., 3, 542-552, doi:10.1016/B978-0-444-53643-3.00106-0.

Schneider von Deimling, T., G. Grosse, J. Strauss, L. Schirrmeister, A. Morgenstern, S. Schaphoff, M. Meinshausen, and J. Boike (2015), Observation-based modelling of permafrost carbon fluxes with accounting for deep carbon deposits and thermokarst activity, Biogeosciences, 12(11), 3469-3488, doi:10.5194/bg-12-3469-2015.

Schuur, E. A. G., et al. (2008), Vulnerability of permafrost carbon to climate change: Implications for the global carbon cycle, BioScience, 58(8), 701, doi:10.1641/B580807.

Schuur, E. A. G., et al. (2015), Climate change and the permafrost carbon feedback, Nature, 520(7546), 171-179, doi:10.1038/nature14338.

Sigman, D. M., M. P. Hain, and G. H. Haug (2010), The polar ocean and glacial cycles in atmospheric $\mathrm{CO}_{2}$ concentration, Nature, 466(7302), 47-55, doi:10.1038/nature09149.

Strauss, J., L. Schirrmeister, G. Grosse, S. Wetterich, M. Ulrich, U. Herzschuh, and H. Hubberten (2013), The deep permafrost carbon pool of the Yedoma region in Siberia and Alaska, Geophys. Res. Lett., 40, 6165-6170, doi:10.1002/2013GL058088.

Tarnocai, C., J. G. Canadell, E. A. G. Schuur, P. Kuhry, G. Mazhitova, and S. Zimov (2009), Soil organic carbon pools in the northern circumpolar permafrost region, Global Biogeochem. Cycles, 23, GB2023, doi:10.1029/2008GB003327.

Van Leer, B. (1977), Towards the ultimate conservative difference scheme: IV. A new approach to numerical convection, J. Comput. Phys., 23, 276-299.

Velichko, A. A., and E. M. Zelikson (2005), Landscape, climate and mammoth food resources in the East European plain during the Late Paleolithic epoch, Quaternary Int., 126-128, 137-151, doi:10.1016/j.quaint.2004.04.019.

Walter Anthony, K. M., et al. (2014), A shift of thermokarst lakes from carbon sources to sinks during the Holocene epoch, Nature, 511(7510), 452-456, doi:10.1038/nature13560.

Wetterich, S., S. Kuzmina, A. A. Andreev, F. Kienast, H. Meyer, L. Schirrmeister, T. Kuznetsova, and M. Sierralta (2008), Palaeoenvironmental dynamics inferred from late Quaternary permafrost deposits on Kurungnakh Island, Lena Delta, northeast Siberia, Russia, Quat. Sci. Rev., 27(15-16), 1523-1540, doi:10.1016/j.quascirev.2008.04.007. 
Yurtsev, B. A. (2001), The Pleistocene "tundra-steppe" and the productivity paradox: The landscape approach, Quat. Sci. Rev., 20(1-3), 165-174, doi:10.1016/S0277-3791(00)00125-6.

Zech, R. (2012), A permafrost glacial hypothesis-Permafrost carbon might help explaining the Pleistocene ice ages, Quat. Sci. J., 61(1), 84-92, doi:10.3285/eg.61.1.07.

Zech, R., Y. Huang, M. Zech, R. Tarozo, and W. Zech (2011), High carbon sequestration in Siberian permafrost loess-paleosols during glacials, Clim. Past, 7(2), 501-509, doi:10.5194/cp-7-501-2011.

Zhu, D., et al. (2015), Improving the dynamics of Northern Hemisphere high-latitude vegetation in the ORCHIDEE ecosystem model, Geosci. Model Dev., 8(7), 2263-2283, doi:10.5194/gmd-8-2263-2015.

Zimov, N. S., S. A. Zimov, A. E. Zimova, G. M. Zimova, V. I. Chuprynin, and F. S. Chapin (2009), Carbon storage in permafrost and soils of the mammoth tundra-steppe biome: Role in the global carbon budget, Geophys. Res. Lett., 36, L02502, doi:10.1029/2008GL036332.

Zimov, S. A., V. I. Chuprynin, A. P. Oreshko, F. S. Chapin, J. F. Reynolds, and M. C. Chapin (1995), Steppe-tundra transition: A herbivore-driven biome shift at the end of the Pleistocene, Am. Nat., 146(5), 765-794.

Zimov, S. A., E. A. G. Schuur, and F. S. Chapin (2006), Permafrost and the global carbon budget, Science, 312(5780), 1612-1613, doi:10.1126/ science.1128908.

Zimov, S. A., N. S. Zimov, A. N. Tikhonov, and F. S. Chapin (2012), Mammoth steppe: A high-productivity phenomenon, Quat. Sci. Rev., 57, 26-45, doi:10.1016/j.quascirev.2012.10.005 